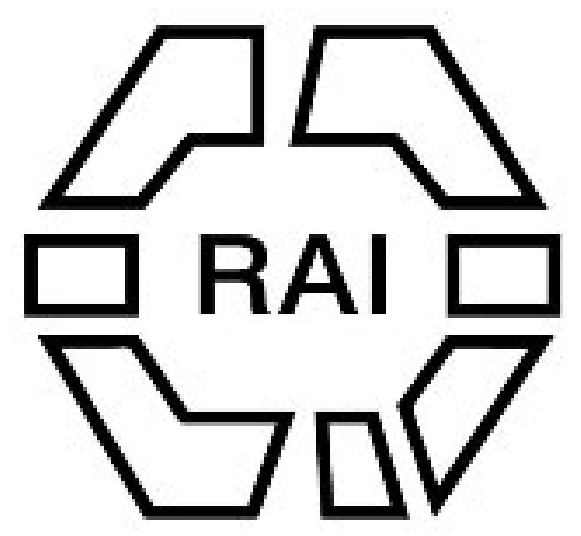

Notes on a Skull Termed "Nabathaean."

Author(s): G. Busk

Source: The Journal of the Anthropological Institute of Great Britain and Ireland, Vol. 8 (1879), pp. 321-323

Published by: Royal Anthropological Institute of Great Britain and Ireland

Stable URL: http://www.jstor.org/stable/2841044

Accessed: $14 / 06 / 2014$ 03:20

Your use of the JSTOR archive indicates your acceptance of the Terms \& Conditions of Use, available at http://www.jstor.org/page/info/about/policies/terms.jsp

JSTOR is a not-for-profit service that helps scholars, researchers, and students discover, use, and build upon a wide range of content in a trusted digital archive. We use information technology and tools to increase productivity and facilitate new forms of scholarship. For more information about JSTOR, please contact support@jstor.org.

Royal Anthropological Institute of Great Britain and Ireland is collaborating with JSTOR to digitize, preserve and extend access to The Journal of the Anthropological Institute of Great Britain and Ireland. 
the prognathous character, accompanied by the remarkable development of the upper part of the superoccipital bone lead us to infer that the position of the individual to which this skull belonged was inferior to that which cranial characters of Chaldæan or Assyrian races produced. If this skull is that of a Nabathæan (and I am of course unable to say anything respecting its age) I have no hesitation in affirming that it presents features which, if exhibited in other adult individuals, indicate an exceptional race, and one which I have not previously observed from these localities.

H. From temple near Wady Hamz; child's calvarium, oval, large parietal bosses, broad alisphenoid, meatus auditorius far behind junction of coronal and sagittal sutures.

K. Nabathæan from temple near Wady Hamz; about 12 years old, m 3 in alveolus, alisphenoido-parietal suture narrow, spheno-occipital suture open.

The theory which was originally offered by M. de Quatrefages, that some of the Palmyrene skulls ("Journ. Anthrop. Institute," Vol. I, 319) may belong to the Chaldæan stock, which is " in part characterised by the absence of the occipital lame and crests, and by the continuity of the curve above and below the latter," indicates his idea that the race in which the occipital lame is greater than ordinary is further from the normal type, and in a different direction than a race in which the occipital squama was less than common. His ideal Chaldæan has therefore nothing to do with the present assumedly "Nabathæan" skull.

\section{NOTES on a SkULL termed "NABATHÆAN."}

By G. Busk, Esq., F.R.S., V.P.A.S.

THIs skull, which is that of an aged man and apparently quite recent, as it has portions of skin still adhering, presents no very striking characteristics, unless it be the greater thickness and forward prominence of the malar bone and outer border of the orbit, which might be taken to indicate a Mongol or Tartar affinity. But to this is opposed the decided dolichocephalism and the want of any obliquity in the orbits, and the prominence or aquiline character of the nasals, \&c. On the whole, I am unable to assign to it any distinct racial characters.*

* It appears, however, closely to resemble in most respects the dolichocephalic skulls from Palmyra described by Dr. Carter Blake ("Journal Anthropological Institute," Vol. I, p. 312, 1871), and which are regarded by Messrs. Marichard and Pruner Beg as "Semite Phé,icien." The modern Srrian skulls would seem, from 


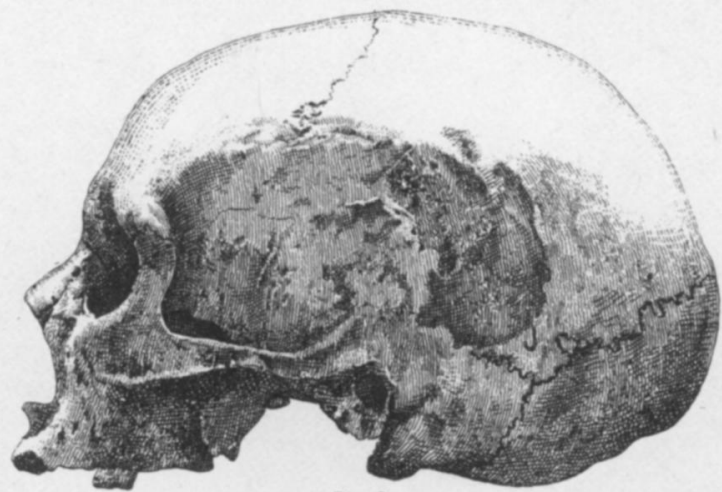

Fig. 1 .
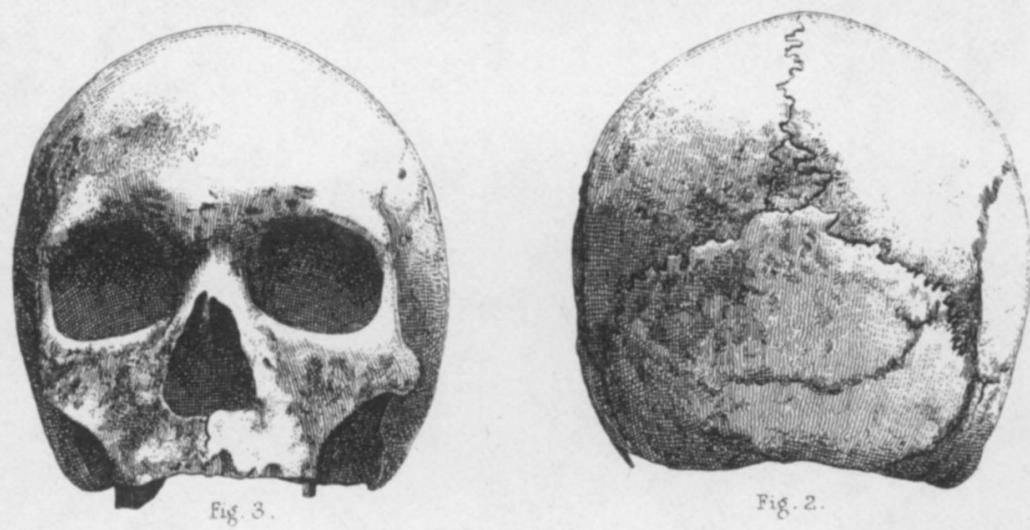

Fig. 2 .
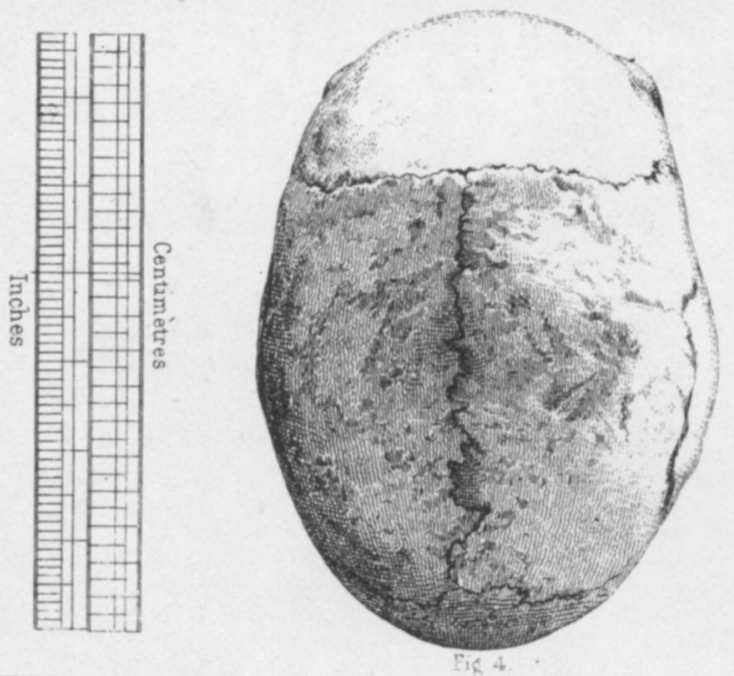

Scale, $\frac{\frac{1}{3}}{2}$ 
Its dimensions, \&c., are given in the subjoined table. The more essential particulars of its conformation may be thus briefly stated.

\section{Norma lateralis. (Fig. 1.)}

The most striking characters afforded by this view are : 1 , the lowness and reclination of the frontal region, and the very considerable production of the occiput, which commences just above the lambdoidal suture. The appearance almost suggests that the skull had been constricted by a bandage. The subinial surface of the occipital ascends but very slightly.

\section{Norma occipitalis. (Fig. 2.)}

In this view the outline above is fastigiate, on the sides somewhat rounded and lofty. The occipital spine wholly undeveloped, and the occipital bone slightly pinched in laterally. The foramen magnum is horizontal.

\section{NoRma FaCIAlis. (Fig. 3.)}

Orbits rectangular ; malar region thick and prominent; nasals prominent not keeled, with an aquiline contour, orifice pyriform; maxillary spine very prominent; zygomata straight and long.

\section{NORMA VERTICALIS.}

Outline regularly oval, the widest part corresponding to the middle of the length of the parietals.

The sutures are all open. The bones generally thick and the entire skull is heavy.

TABLE OF DIMENSIONS, PROPORTIONS, \&c.

\begin{tabular}{|c|c|c|c|c|c|}
\hline 1 & Length & $7 \cdot 4$ & 8 & Zygomatic width.. & $4 \cdot 6$ \\
\hline 2 & Breadth & $5 \cdot 3$ & & & \\
\hline 3 & Height $\quad .$. & $5 \cdot 5$ & $\begin{array}{r}9 \\
10\end{array}$ & $\begin{array}{l}\text { Frontal radius } \\
\text { Vertical }\end{array}$ & $\begin{array}{l}4 \cdot 5 \\
4 \cdot 6\end{array}$ \\
\hline 4 & Least frontal width & $3 \cdot 8$ & $\begin{array}{l}11 \\
12\end{array}$ & $\begin{array}{l}\text { Parietal ", } \\
\text { Occipital } ",\end{array}$ & $\begin{array}{l}4 \cdot 8 \\
4 \cdot 3\end{array}$ \\
\hline 5 & Greatest ditto & $4 \cdot 5$ & $\begin{array}{l}13 \\
14\end{array}$ & $\begin{array}{ll}\text { Maxillary } " & \\
\text { Fronto nasal }, & \ldots\end{array}$ & $\begin{array}{l}4 \cdot 1 \\
3 \cdot 8\end{array}$ \\
\hline 6 & Parietal width & $5 \cdot 3$ & & & \\
\hline 7 & Occipital & $4 \cdot 5$ & 15 & Circumference & $20 \cdot 3$ \\
\hline
\end{tabular}

what is said by Dr. Carter Blake (loc. cit. p. 316), to be extremely brachycephalic. Whether this brachycephalism is due to Turkish, i.e., Tartar blood, or is connected with an Arab descent, is an interesting point. The Hebrew skull is, I believe, usually brachycephalic; whether that of the cognate descendants of Ishmael is so or not, I am ignorant. 
Prof. Owen.-Observations on the Collection of Skulls.

TABLE OF DIMENSIONS, PROPORTIONS, \&c.-continued.

\begin{tabular}{|c|c|c|c|c|c|}
\hline 16 & Longitudinal arc .. & $14 \cdot 6$ & 23 & \multirow{2}{*}{$\begin{array}{l}\text { Occipital transverse } \\
\text { arc }\end{array}$} & \multirow{2}{*}{$11 \cdot 6$} \\
\hline 17 & Frontal $\quad, \ldots$ & $4 \cdot 85$ & & & \\
\hline 18 & Parietal & 51 & 24 & & $\cdot 716$ \\
\hline 19 & Occipital $\quad, \ldots$ & $4 \cdot 6$ & 25 & $\begin{array}{l}\text { Latitudinal index } \\
\text { Altitudinal ", }\end{array}$ & .743 \\
\hline 20 & $\begin{array}{l}\text { Frontal transverse } \\
\text { arc }\end{array}$ & $11 \cdot 65$ & 26 & Gnathic & $\cdot 30$ \\
\hline 21 & $\begin{array}{l}\text { Vertical transverse } \\
\text { arc }\end{array}$ & $12 \cdot 1$ & $\begin{array}{l}27 \\
28\end{array}$ & $\begin{array}{l}\text { Nasal } \\
\text { Orbital }\end{array}$ & .50 \\
\hline 22 & Parietal transverse & $12 \cdot 8$ & & & \\
\hline & $\operatorname{arc}$ & & 29 & Cubic contents & $78 \cdot 5$ \\
\hline
\end{tabular}

Observations on the Collection of SkUlls sent by Capt. Burton, F.R.G.S., \&C., to the British Museum, SePtember, 1878. By Prof. Owen, C.B., F.R.S.

\section{PalmyRa SKULls.}

OF the three skulls from Palmyra submitted to me by Capt. Burton:

One (A) includes the upper jaw and calvarium to near the lambdoidal suture. This indicates a long and narrow cranium; the profile and glabella are very similar to those of the Egyptian skull of the IVth Dynasty, figured in Vol. IV, Pl. XXI, of the "Journal of the Anthropological Institute;" but the frontal bone does not rise quite as high, and the cranium is narrower; the brain was less developed. The upper jaw is a little prognathic. The molar teeth offer the same proportions as in Fig. 2 of the Plate above cited.

The second skull (B) is of a female. The cranium is broader and the vertex higher in proportion to the length of the skull than in A. It is a small skull for a female, but the individual was adult, and had lost the right upper permanent mid-incisor before death, the socket being obliterated by absorption.

The third skull (C) is of a child ; by the state of the dentition about four or five years old.

The racial characters of these skulls are those of the most ancient known Egyptians. They are not Australioid nor Papuan, nor Negroid, nor Mongolian; but of that somewhat negative type termed Indo-European, Aryan or Caucasian, of which the varieties are endless in relation to the manifold habitual exercises of the brain at the several phases of the Caucasian and Aryan civilisations. 